\title{
Bacterial Extracellular Polymers: A Review
}

\author{
Hemlata Sharma ${ }^{1}$, Jyoti Pal ${ }^{2}$ and Deepesh Kumar Neelam ${ }^{1 *}$ (D) \\ ${ }^{1}$ Department of Microbiology, Faculty of Science, JECRC University, \\ Ramchandrapura Industrial Area, Vidhani, Sitapura Extension, Jaipur - 303 905, Rajasthan, India. \\ ${ }^{2}$ LNJN National Institute of Criminology and Forensic Sciences, Rohini, Delhi, India - 110 085, India.
}

\begin{abstract}
Prokaryotic microbial cells especially bacteria are highly emphases for their exopolysaccharides (EPS) production. EPS are the higher molecular weight natural extracellular compounds observe at the surface of the bacterial cells. Nowadays bacterial EPS represent rapidly emerging as new and industrially important biomaterials because it having tremendous physical and chemical properties with novel functionality. Due to its industrial demand as well as research studies the different extraction processes have been discovered to remove the EPS from the microbial biofilm. The novelties of EPS are also based on the microbial habitat conditions such as higher temperature, lower temperature, acidic, alkaliphilic, saline, etc. Based on its chemical structure they can be homopolysaccharide or heteropolysaccharide. EPSs have a wide range of applications in various industries such as food, textile, pharmaceutical, heavy metal recovery, agriculture, etc. So, this review focus on the understanding of the structure, different extraction processes, biosynthesis and genetic engineering of EPS as well as their desirable biotechnological applications.
\end{abstract}

Keywords: Exopolysaccharides, Biosynthesis, Genetic engineering, Industrial applications

*Correspondence: deepesh40neelam@gmail.com

(Received: March 08, 2021; accepted: July 08, 2021)

Citation: Sharma H, Pal J, Neelam DK. Bacterial Extracellular Polymers: A review. J Pure Appl Microbiol. 2021; 15(3):1072-1082. doi: 10.22207/JPAM.15.3.28

C The Author(s) 2021. Open Access. This article is distributed under the terms of the Creative Commons Attribution 4.0 International License which permits unrestricted use, sharing, distribution, and reproduction in any medium, provided you give appropriate credit to the original author(s) and the source, provide a link to the Creative Commons license, and indicate if changes were made. 


\section{INTRODUCTION}

Exopolysaccharides are the key feature of most of the bacterial sufaces ${ }^{1}$. The formation of biofilms takes place through the attachment of bacterial cells to the substratum or cells embedded in a protective extracellular matrix ${ }^{2}$. It is a complex structure of a heterogeneous matrix consists of various molecules ${ }^{3}$. These natural polymers have emerged as a new alternative to synthetic polymers with marvellous physical characteristics, so they have vast industrial applications. This term was first used by Sutherland in 1972 in his exclusive work on marine bacteria producing EPS ${ }^{4}$. EPS finds in two forms viz. EPS (capsular EPS) and soluble EPS (slime) $)^{5,6}$. From the last decades, industries are more emphases on natural polymers production and these natural polymers are used by various pharmaceuticals, food and other industries which are developing remarkable interest in polysaccharides produced by microorganisms ${ }^{7}$. The total EPS yield depends upon microorganisms used and cultivation conditions provided to them ${ }^{8,9}$. Bacterial EPS's have been utilized as bio-absorbents, bio-flocculants and heavy metal removal agents ${ }^{10}$. The main aim of writing this review is to give an overview of the structure, extraction process, biosynthesis, genetic engineering and applications of microbial EPS.

Structure of EPS

Based on the monomeric unit, EPS's are classified as homopolysaccharides and heteropolysaccharides ${ }^{11}$. Homopolysaccharides contain monosaccharides while heteropolysaccharides are composed of more than one type of monosaccharide ${ }^{12}$. EPS is classified based on the number and nature of monomers, bonds between them and the type of linkage ${ }^{11}$. EPS are generally polyanionic due to the presence of uronic acids or ketal-linked pyruvate or inorganic substances like phosphate or sulfate. Some are also neutral macromolecules ${ }^{13}$. A few EPSs may even be polycationic, e.g. polymer obtained from Staphylococcus epidermidis strains ${ }^{14}$. However, the physicochemical factors also affect the production of exopolysaccharides which includes $\mathrm{pH}$, temperature, incubation time, and the constituents of culture media (with various organic and inorganic carbon $(\mathrm{C})$ and nitrogen $(\mathrm{N})$ sources) $)^{15}$.

\section{Extraction of EPS}

Various extraction processes have been developed to recover EPS from biofilm of microbes from different environments to identify the contents of EPS, to analyze various properties (chemical, physical and physicochemical) and to observe the functions of EPS ${ }^{16,17}$. The various extraction methods include chemical or physical and physical and chemical, and analytical methods. It is estimated that extraction methods are dependent on the water solubility of the EPS separated. The extraction methods of EPS should be cost-effective, eco-friendly and do not damage the structure of EPS ${ }^{16}$. The extraction efficiency is calculated as the overall amount of EPS separated from the entire microbial biomass for a particular sample s. $^{5}$.

\section{Physical method}

The physical process mainly involves three extraction techniques i.e. centrifugation, sonication and heating ${ }^{18}$. Researchers explored the reason behind variations in extraction efficiency with different physical methods. These variations in results are because during the extraction procedure by heating, the components of EPS might be hydrolyzed, for this particular case, the proteins and polysaccharide content of EPS ${ }^{18}$. Another study showed that the heating allowed extracting the capsular EPS to flocs ${ }^{19}$. However, several studies suggested that the high EPS extraction yield by the heating methodology could also be thanks to meaningful cell lysis which can lead to high protein content in EPS ${ }^{20,21}$.

\section{Chemical method}

In the chemical method, different chemicals are used which could break the linkage in the matrix so that EPS can be easily released to the external medium containing water. $\mathrm{NaOH}$ treatment can cause the ionization of a great number of charged groups, for instance, carboxylic groups in proteins and polysaccharides. Due to this, a strong repulsion occurs between EPS which enhances its solubility. A lot of polymers can suffer alkaline hydrolysis ${ }^{22}$. In glycoproteins, disulfide bonds can be broken if exposed to basic environments ( $\mathrm{pH}$ above 9), which will promote the extraction of these compounds ${ }^{23}$. The repulsion and solubility between the compounds of the EPS matrix are resultant of the exchange of 
divalent cations with mono-valent cations. Resin, EDTA or EGTA are used for the removal of divalent cations. A high concentration of sodium chloride can also be used to carry out cation exchange. This process has been used in Pseudomonas sp. for the extraction of adhesive exopolymers ${ }^{24,25}$. The extraction of EPS could be increased by destabilizing biofilm in an enzymatic digestion process $^{26}$. Furthermore, ethanol from activated sludge has been used to extract lipids ${ }^{27}$.

\section{Combination of physical and chemical method}

Some studies proposed that the chemical extraction method could be of better performance once it is combined with the physical method i.e. defined shear. The shear is often provided by heat, sonication, or stirring under pre-established conditions. The alkaline and heat treatment has been combined to extract capsular EPS from varied microbial species ${ }^{28}$. On the other hand, shear (stirring) and ion exchange by a Dowex extraction have been used in conjunction to extract EPS from activated sludge and biofilms ${ }^{16,29}$. Formaldehyde $\left(\mathrm{CH}_{2} \mathrm{O}\right)$ and $\mathrm{NaCl}$ was applied in combination with ultrasonication, to extract EPS from an anaerobic sludge $^{30}$. The formaldehyde is added to minimize cell disruption during the extraction process. However, formaldehyde $\left(\mathrm{CH}_{2} \mathrm{O}\right)$ has the capacity to changes the properties of many EPS components ${ }^{31}$. Analytical method

\section{Colorimetric analyses}

The complex composition of EPS in biofilms is made up of carbohydrates, lipids, humic substances, proteins, nucleic acids, etc. Colorimetric analyses are may be used to quantify the components in EPS ${ }^{32}$. The measurement of carbohydrate contents performed by two methodologies i.e. the anthrone method or the phenol-sulfuric acid method. The content of protein might be measured by the Lowry technique, the Press-Man technique, or the total $\mathrm{N}$-content technique ${ }^{16}$. The $\mathrm{m}$-hydroxydiphenyl sulfuric acid method has been used to measure uronic acid content in $\mathrm{EPS}^{33}$. To measure the nucleic acid content, three different methodologies could be used, which are the 4,6-diamidino-2-phenylindole (DAPI) fluorescence method ${ }^{16}$, the UV absorbance method $^{34}$, or the diphenylamine method ${ }^{21}$.

\section{Innovative methods}

EPS structure, functions and conformation examinations are very difficult to work due to their complex composition. However, recent studies in analytical chemistry develop new techniques such as transmission electron microscopy $(\mathrm{TEM})^{35}$, scanning electron microscopy (SEM) $)^{35}$, atomic force microscopy (AFM) ${ }^{36}$, confocal laser scanning microscopy (CLSM) ${ }^{37}$, fourier transform infrared spectroscopy $(\mathrm{FTIR})^{38}$, X-rayphotoelectron spectroscopy (XPS) ${ }^{38}$, nuclear magnetic resonance $(\mathrm{NMR})^{39}$ and 3-dimensional excitation-emission matrix fluorescence spectroscopy (3D-EEM) ${ }^{40}$ which will help in examining the properties of EPS as well as their nature. The qualitative and quantitative analysis of EPS compositions was reported by using chromatography, mass spectrometry and their combination ${ }^{16}$.

\section{Biosynthesis of EPS}

Biosynthesis of homopolysaccharides and heteropolysaccharides take place in differentdifferent pathways.

\section{Synthase dependent pathway}

The synthesis of homopolysaccharides through synthase, a dependent pathway is quite complicated, but specific enzymes make this process easier, by making modifications in initially synthesized homopolysaccharides such as alginate (Table 1) via the polymerization of GDPmannuronic acid monomers, the biosynthesis of alginate takes place too. The enzymes involved in alginate biosynthesis are epimerases, lyases and acetylases $^{41}$. Diverse alginate epimerases (AlgE17) outer of the cell are there that alter the final chemical polymer characteristics through the selective insertion of specific $\beta$-D- mannuronic acid (M) and $\alpha$-L-guluronic acid (G) blocks ${ }^{41,42}$. In recent years, the significance of $P$. aeruginosa was represented as depressingly induces alginate production. The DalgL variant had maximum yields of alginate of equal MW. The higher O-acetylated alginate and lower molecular weight were observed after the overexpression of AlgL. Both are highly focused factors for the pathogenicity of $P$. aeruginos $a^{43}$. Therefore, the biosynthesis of alginate functions as a motley-enzyme complex ${ }^{44}$. A pure EPS of biofilm is bacterial cellulose which is a linear glucan $\beta-(1,4)^{45}$.

The UDP-activated cytosolic glucose monomers follow the cellulose synthase complex that incorporates a preserved catalytic subunit denominated BcsA. It is related to the GT2 family which is known by performs the polymerization 
process through upend the mechanism. The structures of the principal subunit and another subunit, BcsA and BcsB both were identified from specific bacteria that was Rhodobacter sphaeroides, show the cell domain of the BcsAB comprised the GT activity and a PILZ domain for interaction with activator c-diGMP ${ }^{46}$. The periplasmic domain is narrowly linked to a flavodoxin-like domain ${ }^{47,48}$. The entire cell envelope is permeated by cellulose synthase complex and its productivity is very high ${ }^{49}$. The interesting phenomenon of biosynthesis of cellulose was recently described ${ }^{46}$.

\section{Dextrase/Sucrase dependent pathway}

The homopolysaccharide dextran and levan are formed and assembled from the cleavage of sucrose molecules by the action of the extracellular sucrase. After that, the monosaccharide unit is transported to a primer molecule, which may be ramified at distinct levels ${ }^{50,51}$. Further, using different primer molecules leads to high oligosaccharide production ${ }^{52}$.

\section{Wzx/Wzy pathway}

In this pathway activated sugar nucleotide monomers are transferred by an enzyme called glycosyltransferases (GTs). In this manner, the number of GTs available will determine the sequence of the final polymers. Both the side chain and substituents are incorporated adjacent to the backbone, before the completion of the polymer assembly, but the stage at which this incorporation occurs is not clear ${ }^{53,54}$. The Wzx gene encodes the flippase protein which transfers the repeating unit by $\mathrm{H}+$-dependent antiporter mechanism ${ }^{55}$. Different numbers of trans membrane sequences are shown by the structures of the several Wzx proteins, besides lack in similarity. It points out that different types of Wzx protein exist ${ }^{56}$. Evidence has been found to support the preference of the substrate Wzx on kindred O-units further than the first sugar ${ }^{55-57}$. As soon are transferred the repeating units towards the periplasm another enzymes, the polymerase will recognize it and helps in the polymerization of repeating units. This procedure is carried out by the polymerase, sometimes accompanied by a co-polymerase, which may be associated with the process of determining the length of the polymer ${ }^{58,59}$. The Wzx / Wzy pathway is defined by the involvement of the main protein in the transportation and polymerization of specific repeating units, on which the final structure of EPS depends. Various EPS such as xanthan and succinoglycan are synthesized through this pathway ${ }^{60-62}$ (Table 2).

\section{$A B C$ transporter pathway}

Two synthesis strategies dependent on the $A B C$ transporter have been identified. One of these strategies is combined with the synthesis and export of cytosolic glucans ${ }^{63,64}$. The second is the synthesis and export of uncoupled glycans by modifying the non-reducing terminus of the polymer attached to Und-P that ends the chain extension. At this point, the terminator determines the glycan chain length and simultaneously serves as an export signal recognized by the transporter $^{63}$. A terminal residue linked by the WbdD protein ${ }^{65}$ and the end process depends on the chain size and the stereochemistry of the WbdD-WbdA complex ${ }^{65,66}$. To assemble the glycan chain, the domains of GT activity are carried by the WbdA protein. Recently, a protein was described in Raoutella terrigena, that was observed the significant role for polymerization, termination, and quality control within its protein structure ${ }^{67}$. These types of findings show the complexity behind the biosynthesis mechanism. Additionally, specific domain scans could be given within the protein complex. Hence, it was possible to understand an important phase of CPS biosynthesis, whose role is crucial in human pathogens. Recently, in Campylobacter jejuni, the ABC PglK transporter mechanism was described, which is highly dependent on ATP to achieve the transport of lipid-linked oligosaccharide units ${ }^{68}$. The drop-interface-bilayer systems have been novel techniques that have helped to gather the most recent knowledge about the Wza homologs for the export of CPS, allowing to know the complexity of this transport mechanism ${ }^{69}$ and in turn, contributing to the construction of promising perspectives $^{70,71}$.

\section{Engineering strategies}

The specific operons present on the genome which are encrypted in genes for the biosynthesis of EPS. Thus, the number of open reading frames (ORFs) may differ from one to more than 30 ORFs $^{86}$. EPS is composed of all the genes that are essential for its biosynthesis of polysaccharides units, the turning of the repeating units, as well as the polymerization and the final 
Table 1. List of homopolysaccharides and producing bacteria

\begin{tabular}{|c|c|c|c|c|c|c|}
\hline S.No. & EPS & Localization & Polymerisation enzyme & Precursors & Micro-organism & Ref. \\
\hline 1. & Dextran & Extracellular & Dextransucrase & Saccharose & Leuconostoc sp. & 72 \\
\hline 2. & Pullulan & Extracellular & $\begin{array}{l}\text { UDPG- } \\
\text { pyrophosphorylase }\end{array}$ & UDP-d-glucose & $\begin{array}{l}\text { Aureobasidium } \\
\text { Pullulans }\end{array}$ & 73,74 \\
\hline 3. & Levan & Extracellular & Levansucrase & - & $\begin{array}{l}\text { Bacilluslicheniformis, } \\
\text { Acetobacter sp., } \\
\text { Halomonas sp. }\end{array}$ & 75 \\
\hline 4. & Curdlan & Extracellular & Curdlan synthase & UDP-glucose & Rhizobium spp. & 76 \\
\hline 5. & Cellulose & Extracellular & Cellulose synthase & UDP-d-glucose & $\begin{array}{l}\text { Acetobacter } \\
\text { Xylinum }\end{array}$ & 77 \\
\hline
\end{tabular}

polymer transport (Table 3). Besides these, there are some specific genes present on the operon which are involved in sugar precursors synthesis, whereas other genes that provide nucleotide sugar are spread all over the chromosomes ${ }^{62}$. It was observed that most of the bacterial genes could encode more than one polysaccharide biosynthesis pathway ${ }^{87}$. The production of EPS depends upon the regulatory effects and cultivation conditions ${ }^{87,88}$. The various type of carbon (C) and nitrogen (N) sources can affect the polysaccharide's expressions in bacteria ${ }^{89}$. It was found that cdi-GMP has an impact on the biosynthesis of EPS, moreover, overexpression resultant as production of novel EPS ${ }^{90}$. The new binding sites could be affecting the EPS biosynthesis $^{91,92}$.

\section{Applications of EPS Agriculture}

EPS has a wide range of applications in agricultural fields and is known to have the ability to increase productivity. EPS's secreted by microorganisms play a crucial role during soil development ${ }^{102}$. It is also capable of entrapping nutrients and provides protection to microbes against unfavorable environmental conditions by forming niches ${ }^{102-104}$. EPS also plays an important role in protecting a crop against desiccation and predation by other organisms ${ }^{105}$. EPS also protects the seedlings from drought. The ability to freeze water, technically called ice nucleation activity (INA), is widely used in biotechnology, for example for the production of energy-saving artificial snow and ice. Additionally, in industries such as food processing, it has been used during ice-cream production and freezes concentration efficiently avoiding loss of flavor ${ }^{106}$.

\section{Heavy metal degradation}

It has been reported in several studies that EPS has a high affinity for heavy metals present in wastewater ${ }^{107}$. The binding affinity of EPS towards heavy metals depends upon the composition and binding sites present in EPS $^{108}$. EPS is associated with the surface so that it protects micro-organisms from heavy metal toxicity ${ }^{109}$. It has been reported that the adsorption capacity of most of the heavy metals such as copper (Cu), lead (Pb), cadmium (Cd), and zinc ( $\mathrm{Zn})$, etc. depends on the components of EPS, which shows that the main reason for the adsorption performance of EPS is the protein ${ }^{110}$.

The major issues of heavy metal, contamination have been seen in agricultural soils because heavy metals can easily enter into the food chain and possess serious health hazards to the humans as well as ecosystem ${ }^{111}$. Toxic heavy metals include cadmium, lead, copper, zinc and manganese ${ }^{112}$.

\section{Biomedical applications}

EPS's have a wide range of applications in the biomedical sector. It is used as a plasma volume expander for controlling wound shock ${ }^{113,114}$, as an antiacid stomach protector in capsules and as a stabilizing agent in pharmaceutical suspensions and emulsions ${ }^{115}$. It is also used during eye surgery, in wound healing, used in cosmetics, in the treatment of osteoarthritis ${ }^{116}$, as a drug-controlled release carrier ${ }^{117}$ and also used in skin repair ${ }^{118}$.

\section{Food applications}

The need of today's hour is the healthier food without compromising with the safety of 
food $^{119}$. There are a lot of microbes producing EPS for eg. lactic acid bacteria mainly produce EPS which improves the quality, texture and safety of various food products and also inhibits the growth of disease-causing organisms in food ${ }^{120,121}$. The EPS in the food industry has been used as an emulsifier, stabilizer and thickener. It is also used in the packaging of food products. Mostly xanthan, gellan and cellulose which are secreted by bacteria other than lactic acid bacteria, are predominantly used in the food industry ${ }^{122}$.

\section{CONCLUSION}

As described in this review, It is now widely considered that bacterial EPS plays a very important role in various industrial applications. Moreover, EPSs biosynthesis is a complicated process through which various alterations occur and resultant many number of EPSs produces on bacterial cell surface, which have a valuable range of physicochemical properties and highly promising commercial applications. However, the EPS extraction methods from cell surface still required the some novel techniques or tricks that will be easy to handle, time consuming and more effective for understanding of mechanism involved in synthesis and excretion. This study showed the role of EPS in the food, pharmaceutical, heavy metal recovery and agriculture field, but there is still much to learn about their functions in the environment. To understand more about biopolymers synthesis, it will be necessary to explore insight into the some extremophiles from extreme condition these EPSs are highly stable at various physical as well as on chemical parameters more than mesophilic bacterial EPSs. On the other hand genetic engineering is the new tools for changes in the properties of molecules that will be possible by genome annotation and construction of EPS biosynthetic pathways in bacterial cell to understand about how they will incorporate and how they will be affected. The big research gaps still remain that no method exists to extract all microbial polysaccharides but in upcoming scientific studies it could be possibility to explain about EPSs with their specific structure and functions.

\section{ACKNOWLEDGMENTS}

All listed author(s) are thankful to JECRC

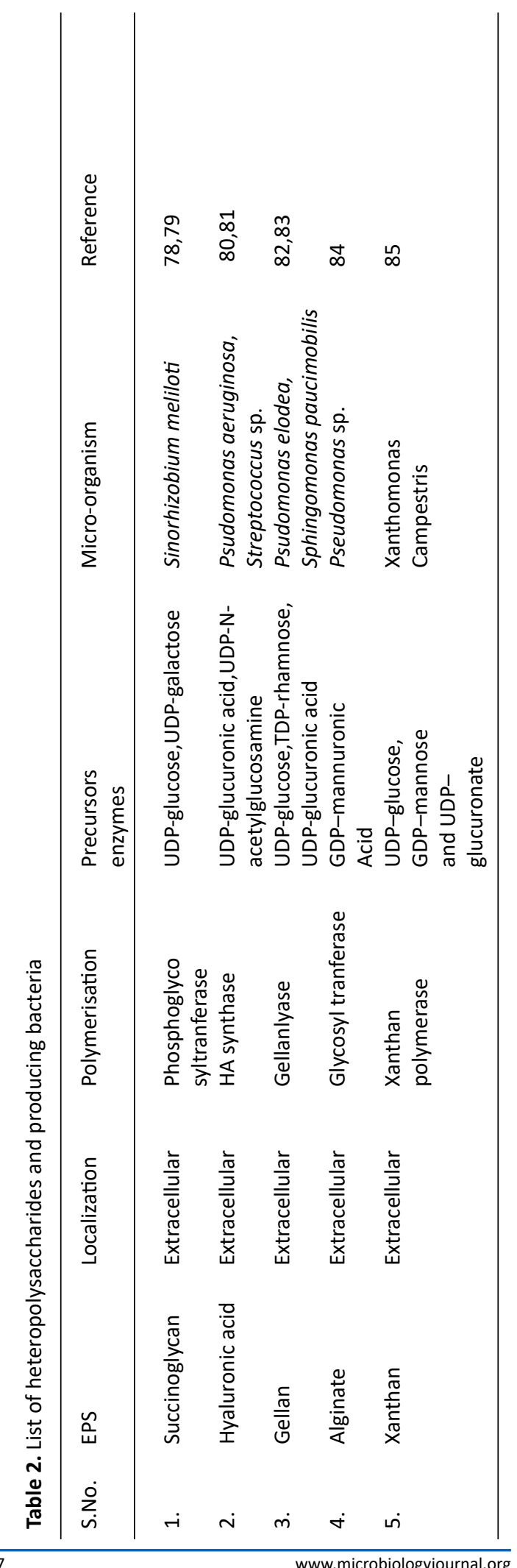

Journal of Pure and Applied Microbiology 
Table 3. List of genes responsible for EPS production

\begin{tabular}{llll}
\hline EPS & Name of the Bacteria & Gene & Reference \\
\hline Xanthan & Xanthomonas Campestris & gum D & 93 \\
Hyaluronan & Streptococcus zooepidermicus & has A & 94 \\
Cellulose & Acetobacter $x$ linus & bcsA & 95 \\
Levan & Erwinia amylovora & rlsA & 96 \\
Gellan & Sphingomonas paucimobilis & pgm G & 97 \\
Alginate & Pseudomans aeruginosa & AlgD, AlgC, & $98,99,100,101$ \\
& & AlgR ,AlgB, \\
& & AlgZ \\
\hline
\end{tabular}

University for providing the related support to compile this work.

\section{CONFLICT OF INTEREST}

The authors declare that there is no conflict of interest.

\section{AUTHORS' CONTRIBUTION}

All authors listed have made a substantial, direct and intellectual contribution to the work, and approved it for publication.

\section{FUNDING}

None.

\section{DATA AVAILABILITY}

All datasets generated or analyzed during this study are included in the manuscript.

\section{ETHICS STATEMENT}

This article does not contain any studies with human participants or animals performed by any of the author.

\section{REFERENCES}

1. Whitfield C, Wear SS, Sande C. Assembly of bacterial capsular polysaccharides and exopolysaccharides. Annu Rev Microbiol. 2020;74:521-543. doi: 10.1146/ annurev-micro-011420-075607

2. Pinto RM, Lopes-de-Campos D, Martins MCL, Van Dijck P, Nunes C, Reis S. Impact of nanosystems in Staphylococcus aureus biofilms treatment. FEMS Microbiol Rev. 2019;43(6):622-641. doi: 10.1093/ femsre/fuz021

3. MC Swain BS, Irvine RL, Hausner M, Wilderer PA. Composition and distribution of extracellular polymeric substances in aerobic flocs and granular sludge. Appl Environ Microbiol. 2005;71:1051-1057. doi: 10.1128/AEM.71.2.1051-1057.2005

4. Sutherland IW. Bacterial exopolysaccharides. Adv
Microb Phys. 1972;8:143-213. doi: 10.1016/S00652911(08)60190-3

5. Nielsen PH, Jahn A. Extraction of EPS. Microbial Extracellular Polymeric Substances. 1999:49-72. doi: 10.1007/978-3-642-60147-7_3

6. Laspidou CS, Rittmann BE. A unified theory for extracellular polymeric substances, soluble microbial products, and active and inert biomass. Water Res. 2002;36(11):2711-2720. doi: 10.1016/S00431354(01)00413-4

7. Sutherland IW. Microbial polysaccharides from Gramnegative bacteria. Int Dairy J. 2001;11(9):663-674. doi: 10.1016/S0958-6946(01)00112-1

8. Angel SJ, Vidyadharani G, Santhosh S, Dhandapani R. Optimization and Characterisation of Thermo Stable Exopolysaccharide Produced from Bacillus licheniformis WSF-1 Strain. J Polym Environ. 2018;26(4):3824-3833. doi: 10.1007/s10924-0181261-0

9. Hu X, Pang X, Wang PG, Chen M. Isolation and characterization of an antioxidant exopolysaccharide produced by Bacillus sp. S-1 from Sichuan Pickles. Carbohydr Polym. 2019;204:9-16. doi: 10.1016/j. carbpol.2018.09.069

10. Liang TW, Wang SL. Recent advances in exopolysaccharides from Paenibacillus spp.: production, isolation, structure, and bioactivities. Mar Drugs. 2015;13(4):1847-1863. doi: 10.3390/ md13041847

11. Ruas-Madiedo P, Hugenholtz J, Zoon P. An overview of the functionality of exopolysaccharides produced by lactic acid bacteria. Int Dairy J. 2002;12(2-3):163-171. doi: 10.1016/S0958-6946(01)00160-1

12. Stewart-Tull DES. The immunological activities of bacterial peptidoglycans. Annu Rev Microbiol.1980;34:311-340. doi: 10.1146/annurev. mi.34.100180.001523

13. Sutherland M, Vuuren HJJ, Martha M. Cloning, sequence and in vitro transcription/translation analysis of a 3.2-kb EcoRI HindIII fragment of Leuconostoc oenos bacteriophage L10 gene. Gene. 1994;148(1):125-129. doi: 10.1016/0378-1119(94)90245-3

14. Mack D, Haeder M, Siemssen N, Laufs R. Association of biofilm production of coagulase-negative staphylococci with expression of a specific polysaccharide intercellular adhesin. J Infect Dis. 1996;174(4):881- 
883. doi: $10.1093 /$ infdis/174.4.881

15. Heumann D, Barras C, Severin A, Glauser MP, Tomasz A. Gram-positive cell walls stimulate synthesis of tumor necrosis factor alpha and interleukin- 6 by human monocytes. Infect Immun. 1994;62(2):2715-2721. doi: 10.1128/iai.62.7.2715-2721.1994

16. Frolund B, Palmgren R, Keiding K, Nielsen PH. Extraction of extracellular polymers from activated sludge using a cation exchange resin. Water Res. 1996;30(8):17491758. doi: 10.1016/0043-1354(95)00323-1

17. Dignac MF, Urbain V, Rybacki D, Bruchet A, Snidaro D, Scribe P. Chemical description of extracellularpolymers: Implication on activated sludge floc structure. Water Sci Technol. 1998;38(8-9):45-53. doi: 10.2166/ wst.1998.0789

18. Comte S, Guibaud G, Baudu M. Relations between extraction protocols for activated sludge extracellular polymeric substances (EPS) and EPS complexation properties: part I:Comparison of the efficiency of eight EPS extraction methods. Enzym Microb Technol. 2006;38(1-2):237-245. doi: 10.1016/j. enzmictec.2005.06.016

19. Tapia J, Munoz J, Gonzalez F, Blazquez M, Malki M, Ballester A. Extraction of extracellular polymeric substances from the acidophilic bacterium Acidiphilium 3.2 sup (5). Water Sci Technol. 2009;59(10):1959-1967. doi: 10.2166/wst.2009.192

20. Frolund B, Palmgren R, Keiding K, Nielsen P. Extraction of activated sludge exopolymers by a cation exchange resin. Water Res. 1995;56:216-230.

21. Liu H, Fang HH. Extraction of extracellular polymeric substances (EPS) of sludges. J Biotechnol. 2002;95(3):249-256. doi: 10.1016/S01681656(02)00025-1

22. Hancock I, Poxton I. Bacterial cell surface techniques. Wiley \& Sons Inc. 1988;273.

23. Zayas JF. Solubility of proteins. In Functionality of Proteins in Food. Springer Berlin Heidelberg. 1997:675. doi: 10.1007/978-3-642-59116-7_2

24. Read R, Costerton J. Purification and characterization of adhesive exopolysaccharides from Pseudomonas putida and Pseudomonas fluorescens. Can J Microbiol. 1987;33(12):1080-1090. doi: 10.1139/m87-189

25. Christensen BE, Kjosbakken J, Smidsrod O. Partial chemical and physical characterization of two extracellular polysaccharides produced by marine, periphytic Pseudomonas sp. strain NCMB 2021. Appl Environ Microbiol. 1985;50(4):837-845. doi: 10.1128/ aem.50.4.837-845.1985

26. Tago Y, Aida K. Exocellular mucopolysaccharide closely related to bacterial floc formation. Appl Environ Microbiol. 1977;34(3):308-314. doi: 10.1128/ aem.34.3.308-314.1977

27. Forster C, Clarke A. The production of polymer from activated sludge by ethanolic extraction and its relation to treatment plant operation. Water Pollut Control. 1983;82:430-433.

28. Breedveld $\mathrm{M}$, Zevenhuizen L, Zehnder A. Osmotically induced oligo-and polysaccharide synthesis by Rhizobium meliloti SU-47. J Gen Microbiol. 1990;136(12):2511-2519. doi: 10.1099/00221287136-12-2511
29. Brown MJ, Lester JN. Comparison of bacterial extracellular polymer extraction methods. Appl Environ Microbiol. 1980;40(2):179-185. doi: 10.1128/ aem.40.2.179-185.1980

30. Jia X, Furumai H, Fang HH. Yields of biomass and extracellular polymers in four anaerobic sludges. Environ Technol. 1996;17(3):283-291. doi: 10.1080/09593331708616386

31. Underwood G, Paterson D, Parkes RJ. The measurement of microbial carbohydrate exopolymers from inter tidal sediments. Limnol Oceanogr. 1995;40(7):1243-1253. doi: 10.4319/lo.1995.40.7.1243

32. Raunkjær K, Hvitved-Jacobsen T, Nielsen PH. Measurement of pools of protein, carbohydrate and lipid in domestic wastewater. Water Res. 1994;28(2):251-262. doi: 10.1016/00431354(94)90261-5

33. Blumenkrantz N, Asboe-Hansen G. New method for quantitative determination of uronic acids. Anal Biochem. 1973;54(2):484-489. doi: 10.1016/00032697(73)90377-1

34. Sheng GP, Yu HQ, Yu Z. Extraction of the extracellular polymeric substances from a photosynthetic bacterium Rhodopseudomonas acidophila. Appl Microbiol Biotechnol. 2005;67:125-130. doi: 10.1007/s00253004-1704-5

35. Beech IB, Cheung CWS, Johnsom DB, Smith $J R$. Comparative studies of bacterial biofilms. on steel surface using atomic force microscopy and environmental scanning electron microscopy. Biofouling. 1996;10(1-3):65-77. doi: 10.1080/08927019609386271

36. Van der Aa BC, Dufrene YF. In situ characterization of bacterial extracellular polymeric substances by AFM. Colloids Surf B. 2002;23(2-3):173-182. doi: 10.1016/ S0927-7765(01)00229-6

37. Zhang T, Fang HHP. Quantification of extracellular poplymeric substances in biofilms by confocal laser scanning microscopy. Biotechnol Lett. 2001;23:405409. doi: 10.1023/A:1005620730265

38. Omoike A, Chorover J. Adsorption to goethite of extracellular polymeric substances from Bacillus subtilis. Geochim Cosmochim Acta. 2006;70(4):827838. doi: 10.1016/j.gca.2005.10.012

39. Manca MC, Lama L, Improta R, Esposito E, Gambacorta A, Nicolaus B. Chemical composition of two exopolysaccharides from Bacillus thermoantarcticus. Appl Environ Microbiol. 1996;62(9);3265-3269. doi: 10.1128/aem.62.9.3265-3269.1996

40. Sheng GP, Yu HQ. Characterization of extracellular polymeric substances of aerobic and anerobic sludge using 3-dimensional excitation and emission matrix fluorescence spectroscopy. Water Res. 2006;40(6):1233-1239. doi: 10.1016/j. watres.2006.01.023

41. Hay ID, Rehman ZU, Moradali MF, Wang Y, Rehm BHA. Microbial alginate production, modification and its applications. Microb Biotechnol. 2013;6(6):637-650. doi: 10.1111/1751-7915.12076

42. Ertesvag $\mathrm{H}$. Alginate-modifying enzymes: biological roles and biotechnological uses. Front Microbiol. 
2015;6:523. doi: 10.3389/fmicb.2015.00523

43. Wang Y, Moradali MF, Goudarztalejerdi A, Sims IM, Rehm BHA. Biological function of a polysaccharide degrading enzyme in the periplasm. Sci Rep. 2016;6:31249. doi: 10.1038/srep31249

44. Maleki S, Almaas E, Zotchev S, Valla S, Ertesvag H. Alginate biosynthesis factories in Pseudomonas fluorescens: Localization and correlation with alginate production level. Appl Environ Microb. 2016;82(4):1227-1236. doi: 10.1128/AEM.03114-15

45. Augimeri RV, Varley AJ, Strap JL. Establishing a role for bacterial cellulose in environmental interactions: lessons learned from diverse biofilm-producing proteobacteria. Front Microbiol. 2015;6:1282. doi: 10.3389/fmicb.2015.01282

46. McNamara JT, Morgan JLW, Zimmer J. A molecular description of cellulose biosynthesis. Annu Rev Biochem. 2015;84:895-921. doi: 10.1146/annurevbiochem-060614-033930

47. Morgan JL, Strumillo J, Zimmer J. Crystallographic snapshot of cellulose synthesis and membrane translocation. Nature. 2013;493(7431):181-186. doi: 10.1038/nature11744

48. Morgan JL, McNamara JT, Zimmer J. Mechanism of activation of bacterial cellulose synthase by cyclic di-GMP. Nat Struct Mol Biol. 2014;21:489-496. doi: 10.1038/nsmb.2803

49. Jang WD, Hwang JH, Kim HU, Ryu JY, Lee SY. Bacterial cellulose as an example product for sustainable production and consumption. Microb Biotechnol. 2017;10(5):1181-1185. doi: 10.1111/1751-7915.12744

50. Ua-Arak T, Jakob F, Vogel RF. Fermentation pH modulates the size distributions and functional properties of Gluconobacter albidus TMW 2.1191 levan. Front Microbiol. 2017;8:807. doi: 10.3389/ fmicb.2017.00807

51. Srikanth R, Reddy CH, Siddartha G, Ramaiah MJ, Uppuluri KB. Review on production, characterization and applications of microbial levan. Carbohydr Polym. 2015;120:102-114. doi: 10.1016/j.carbpol.2014.12.003

52. Hu Y, Winter V, Chen XY, Ganzle MG. Effect of acceptor carbohydrates on oligosaccharide and polysaccharide synthesis by dextransucrase DsrM from Weissella cibaria. Food Res Int. 2017;99(Pt 1):603-611. doi: 10.1016/j.foodres.2017.06.026

53. Baker P, Whitfield GB, Hill PJ, et al. Characterization of the Pseudomonas aeruginosa glycoside hydrolase PsIG reveals that its levels are critical for Psl polysaccharide biosynthesis and biofilm formation. I Biol Chem. 2015;290(47):28374-28387. doi: 10.1074/jbc. M115.674929

54. Schmid J, Sieber V. Enzymatic transformations involved in the biosynthesis of microbial exo-polysaccharides based on the assembly of repeat units. Chembiochem. 2015;16(8):1141-1147. doi: 10.1002/cbic.201500035

55. Islam ST, Lam JS. Synthesis of bacterial polysaccharides via the Wzx/Wzy-dependent pathway. Can J Microbiol. 2014;60(11):697-716. doi: 10.1139/cjm-2014-0595

56. Hong $Y$, Liu MA, Reeves PR. Progress in our understanding of Wzx flippase for translocation of bacterial membrane lipid-linked oligosaccharide. J Bacteriol. 2018;200(1):e00154-17. doi: 10.1128/ JB.00154-17

Journal of Pure and Applied Microbiology
57. Liu MA, Stent TL, Hong $Y$, Reeves PR. Inefficient translocation of a truncated $\mathrm{O}$ unit by a Salmonella Wzx affects both $\mathrm{O}$-antigen production and cell growth. FEMS Microbiol Lett. 2015;362(9):fnv053. doi: 10.1093/femsle/fnv053

58. Whitfield C. Polymerases glycan chain-length control. Nat Chem Biol. 2010;6:403-404. doi: 10.1038/ nchembio.376

59. Rehm BHA. Bacterial polymers: biosynthesis, modifications and applications. Nat Rev Micro. 2010;8(8):578-592. doi: 10.1038/nrmicro2354

60. Freitas F, Torres CAV, Reis MAM. Engineering aspects of microbial exopolysaccharide production. Bioresour Technol. 2017;245(Part B):1674-1683. doi: 10.1016/j. biortech.2017.05.092

61. Schmid J, Sperl N, Sieber V. A comparison of genes involved in sphingan biosynthesis brought up to date. Appl Microbiol Biotechnol. 2014;98(18):7719-7733. doi: 10.1007/s00253-014-5940-z

62. Schmid J, Sieber V, Rehm B. Bacterial exopolysaccharides: biosynthesis pathways and engineering strategies. Front Microbiol. 2015;6:496. doi: $10.3389 /$ fmicb.2015.00496

63. Kos V, Cuthbertson L, Whitfield C. The Klebsiella pneumoniae $\mathrm{O} 2 \mathrm{a}$ antigen defines a second mechanism for $\mathrm{O}$ antigen ATP binding cassette transporters. J Biol Chem. 2009;284(5):2947-2956. doi: 10.1074/jbc. M807213200

64. Mann E, Mallette E, Clarke BR, Kimber MS, Whitfield C. The Klebsiella pneumoniae 012 ATP-binding cassette $(A B C)$ transporter recognizes the terminal residue of its O-antigen polysaccharide substrate. $J$ Biol Chem. 2016;291(18):9748-9761. doi: 10.1074/ jbc.M116.719344

65. Hagelueken $\mathrm{G}$, Huang $\mathrm{H}$, Clarke BR, Lebl T, Whitfield C, Naismith JH. Structure of WbdD: a bifunctional kinase and Methyl transferase that regulates the chain length of the $\mathrm{O}$ antigen in Escherichia coli O9a. Mol Microbiol. 2012;86(3):730-742. doi: 10.1111/mmi.12014

66. King JD, Berry S, Clarke BR, Morris RJ, Whitfield C. Lipopolysaccharide $O$ antigen size distribution is determined by a chain extension complex of variable stoichiometry in Escherichia coli 09a. Proc Natl Acad Sci USA. 2014;111:6407-6412. doi: 10.1073/ pnas. 1400814111

67. Williams DM, Ovchinnikova OG, Koizumi A, et al. Single polysaccharide assembly protein that integrates polymerization, termination, and chain-length quality control. Proc Nat/ Acad SciUSA. 2017;114:E1215-E1223. doi: 10.1073/pnas.1613609114

68. Perez C, Gerber S, Boilevin J, et al. Structure and mechanism of an active lipid-linked oligosaccharide flippase. Nature. 2015;524(7566):433-438. doi: 10.1038/nature14953

69. Kong L, Almond A, Bayley H, Davis BG. Chemical polyglycosylation and nanolitre detection enables single molecule recapitulation of bacterial sugar export. Nat Chem. 2016;8:461-469. doi: 10.1038/ nchem. 2487

70. Locher KP. Mechanistic diversity in ATP-binding cassette $(A B C)$ transporters. Nat Struct Mol Biol. 2016;23(6):487-493. doi: 10.1038/nsmb.3216 
71. Woodward L, Naismith JH. Bacterial polysaccharide synthesis and export. Curr Opin Struct Bio. 2016;40:8188. doi: 10.1016/j.sbi.2016.07.016

72. Santos M, Teixeira J, Rodrigues A. Production of dextransucrase, dextran and fructose from sucrose using Leuconostoc mesenteroides NRRL B512 (f). Biochem Eng J. 2000;4(3):177-188. doi: 10.1016/ S1369-703X(99)00047-9

73. Jiang L. Optimization of fermentation conditions for pullulan production by Aureobasidium pullulan using response surface methodology. Carbohydr Polym. 2010;79(2):414-417. doi: 10.1016/j. carbpol.2009.08.027

74. Jiang L, Wu S, Kim JM. Effect of different nitrogen sources on activities of UDPG-pyrophosphorylase involved in pullulan synthesis and pullulan production by Aureobasidium pullulans. Carbohydrate polymers. 2011;86(2):1085-1088. doi: 10.1016/j. carbpol.2011.05.016

75. Gojgic-Cvijovic GD, Jakovljevic DM, Loncarevic BD, et al. Production of levan by Bacillus licheniformis NS032 in sugar beet molasses-based medium. Int J Biol Macromol. 2019;121:142-151. doi: 10.1016/j. ijbiomac.2018.10.019

76. Pavlova K, Panchev I, Hristozova T. Physico-chemical characterization of exo mannan from Rhodotorula acheniorum MC. World J Microbiol Biotechnol. 2005;21:279-283. doi: 10.1007/s11274-004-3632-z

77. Hwang JW, Yang YK, Hwang JK, Pyun YR, Kim YS. Effects of $\mathrm{pH}$ and dissolved oxygen on cellulose production by Acetobacter xylinum BRC5 in agitated culture. J Biosci Bioeng. 1999;88:183-188. doi: 10.1016/S13891723(99)80199-6

78. Arnold MFF, Penterman J, Shabab M, Chen EJ, Walker GC. Important Late-Stage Symbiotic Role of the Sinorhizobium meliloti exopolysaccharide succinoglycan. J Bacteriol. 2018;200(13). doi: 10.1128/ JB.00665-17

79. Leigh JA, Walker GC. Exopolysaccharides of Rhizobium: synthesis, regulation and symbiotic function. Trends Genet. 1994;10(2):63-67. doi: 10.1016/01689525(94)90151-1

80. Huang G, Chen J. Preparation and applications of hyaluronic acid and its derivatives. Int $\mathrm{J} \mathrm{Biol}$ Macromol. 2019;125:478-484. doi: 10.1016/j. ijbiomac.2018.12.074

81. Sugahara K, Schwartz NB, Dorfman A. Biosynthesis of hyaluronic acid by Streptococcus. J Biol Chem. 1979;254(14):6252-6261. doi: 10.1016/S00219258(18)50356-2

82. Hashimoto W, Maesaka K, Sato N, et al. Microbial System for Polysaccharide Depolymerization: Enzymatic Route for Gellan Depolymerization by Bacillus sp. GL1. Arch Biochem Biophys. 1997;339(1):17-23. doi: 10.1006/ abbi.1996.9851

83. Martins LO, Sa-Correia I. Gellan gum biosynthetic enzymes in producing and nonproducing variants of Pseudomonas elodea. Biotechnol Apll Bioc. 1991;14(3):357-364.

84. Hay ID, Ur Rehman Z, Ghafoor A, Rehm BH. Bacterial biosynthesis of alginates. J Chem Technol Biotechnol. 2010;85(6):752-759. doi: 10.1002/jctb.2372
85. Kalogiannis S, lakovidou G, Liakopoulou-Kyriakides M, Kyriakidis DA, Skaracis GN. Optimization of xanthan gum production by Xanthomonas campestris grown in molasses. Process Biochem. 2003;39(2):249-256. doi: 10.1016/\$0032-9592(03)00067-0

86. Pan YJ, Lin TL, Chen CT, et al. Genetic analysis of capsular polysaccharide synthesis gene clusters in 79 capsular types of Klebsiella spp. Sci Rep. 2015;5:15573. doi: 10.1038/srep15573

87. Zeidan AA, Poulsen VK, Janzen T, et al. Polysaccharide production by lactic acid bacteria: from genes to industrial applications. FEMS Microbiol Rev. 2017;41(Suppl 1):S168-S200. doi: 10.1093/femsre/ fux017

88. Cheng X, Zheng X, Zhou X, et al. Regulation of oxidative response and extracellular polysaccharide synthesis by a di adenylate cyclase in Streptococcus mutans. Environ Microbiol. 2016;18(3):904-922. doi: 10.1111/14622920.13123

89. Rutering $M$, Schmid J, Ruhmann B, Schilling M, Sieber V. Controlled production of polysaccharides-exploiting nutrient supply for levan and heteropolysaccharide formation in Paenibacillus sp. Carbohydr Polym. 2016;148:326-334. doi: 10.1016/j.carbpol.2016.04.074

90. Perez-Mendoza D, Rodriguez-Carvaja IMA, RomeroJimenez $L$, et al. Novel mixed-linkage b-glucan activated by c-di-GMP in Sinorhizobium meliloti. Proc Natl Acad Sci USA. 2015;112(7):E757-E765. doi: 10.1073/pnas.1421748112

91. Perez-Mendoza D, Bertinetti D, Lorenz R, Gallegos M-T, Herberg FW, Sanjuan J. A novel c-di-GMP binding domain in glycosyltransferase BgsA is responsible for the synthesis of a mixed-linkage b-glucan. Sci Rep. 2017;7:8997. doi: 10.1038/s41598-017-09290-2

92. Schaper S, Steinchen W, Krol E, et al. AraC-like transcriptional activator CuxR binds c-di-GMP by a PilZ-like mechanism to regulate extracellular polysaccharide production. Proc Natl Acad Sci USA. 2017;114(24):E4822-E4831. doi: 10.1073/ pnas. 1702435114

93. Chou FL, Chou HC, Lin YS, et al. The Xanthomonas campestris gumDGene Required for Synthesis of Xanthan Gum Is Involved in Normal Pigmentation and Virulence in Causing Black Rot. Biochem Biophys Res Commun. 1997;233(1):265-269. doi: 10.1006/ bbrc.1997.6365

94. Gunasekaran V, Gowdhaman D, Ponnusami V. Role of membrane proteins in bacterial synthesis of hyaluronic acid and their potential in industrial production. Int $J$ Biol Macromol. 2020;164:1916-1926. doi: 10.1016/j. ijbiomac.2020.08.077

95. Ross P, Mayer R, Benziman M. Cellulose biosynthesis and function in bacteria. Microbiol Mol Biol Rev. 1991;55(1):35-58. doi: 10.1128/MMBR.55.1.3558.1991

96. Zhang $\mathrm{Y}$, Geider K. Molecular analysis of the rlsA gene regulating levan production by the fireblight pathogen Erwinia amylovora. Physiol Mol Plant Pathol. 1999;54(5-6):187-201. doi: 10.1006/pmpp.1999.0198

97. Videira PA, Cortes LL, Fialho AM, Sa-Correia I. Identification of the pgmG gene, encoding a bifunctional protein with phosphoglucomutase and 
phosphomannomutase activities, in the gellan gumproducing strain Sphingomonas paucimobilis ATCC 31461. Appl Environ Microbiol. 2000;66(5):2252-2258. doi: 10.1128/AEM.66.5.2252-2258.2000

98. Yu H, Mudd M, Boucher JC, Schurr MJ, Deretic V. Identification of the algZ gene upstream of the response regulator algR and its participation in control of alginate production in Pseudomonas aeruginosa. J Bacteriol. 1997;179(1):187-193. doi: 10.1128/ jb.179.1.187-193.1997

99. Firoved AM, Boucher JC, Deretic V. Global genomic analysis of AlgU ( $\sigma \mathrm{E})$-dependent promoters (sigmulon) in Pseudomonas aeruginosa and implications for inflammatory processes in cystic fibrosis. J Bacteriol. 2002;184(4):1057-1064. doi: 10.1128/jb.184.4.10571064.2002

100. Wozniak DJ, Sprinkle AB, Baynham PJ. Control of Pseudomonas aeruginosa algZ expression by the alternative sigma factor AlgT. $J$ Bacteriol. 2003;185(24):7297-7300. doi: 10.1128/ JB.185.24.7297-7300.2003

101. Muhammadi, Ahmed N. Genetics of bacterial alginate: alginate genes distribution, organization and biosynthesis in bacteria. Curr Genomics. 2007;8(3):191202. doi: $10.2174 / 138920207780833810$

102. Costa O, Raaijmakers J, Kuramae E. Microbial extracellular polymeric substances: ecological function and impact on soil aggregation. Front Microbiol. 2018;9:1636. doi: 10.3389/fmicb.2018.01636

103. FlemmingHC. EPS-then and now. Microorganisms. 2016;4(4):41. doi: 10.3390/microorganisms4040041

104. Velmourougane K, Prasanna R, Saxena A. Agriculturally important microbial biofilms: Present status and future prospects. J Basic Microbiol. 2017;57(7):548-573. doi: 10.1002/jobm.201700046

105. Looijesteijn PJ, Trapet L, de Vries E, Abee T, Hugenholtz J. Physiological function of exopolysaccharides produced by Lactococcus lactis. Int J Food Microbiol. 2001;64(1):71-80. doi: 10.1016/S0168-1605(00)004372

106. Lundheim R, Zacchariassen KE. Applications of biological ice nucleators. In: Margesin R, Schinner $F$ (eds) Biotechnological applications of cold-adapted organisms.Springer Berlin Heidelberg NewYork. 1999:309-317. doi: 10.1007/978-3-642-58607-1_20

107. Sheng GP, Xu J, Li WH, Yu HQ. Quantification of the interactions between $\mathrm{Ca}^{2+}, \mathrm{Hg}^{2+}$ and extracellular polymeric substances (EPS) of sludge. Chemosphere. 2013;93(7):1436-1441. doi: 10.1016/j. chemosphere.2013.07.076

108. Aquino S, Stuckey D. Soluble microbial products formation in anaerobic chemostats in the presence of toxic compounds. Water Res. 2004;38(2):255-266. doi: 10.1016/j.watres.2003.09.031

109. Song W, Pan X, Mu S, Zhang D, Yang X, Lee DJ. Biosorption of $\mathrm{Hg}$ (II)onto goethite with extracellular polymeric substances. Bioresour Technol. 2014;160:119-122. doi: 10.1016/j.biortech.2013.12.052
110. Liu W, Zhang J, Jin Y, Zhao X, Cai Z. Adsorption of Pb (II), $\mathrm{Cd}$ (II) and Zn(II) by extracellular polymeric substances extracted from aerobic granular sludge:Efficiency of protein. J Environ Chem Eng. 2015;3(2):1223-1232. doi: 10.1016/j.jece.2015.04.009

111. Kaur R, Bhatti SS, Singh S, Singh J, Singh S. Phytoremediation of heavy metals using cotton plant: a field analysis. Bull Environ Contam Toxicol. 2018;101(5):637-643. doi: 10.1007/s00128-018-24728

112. Karthik C, Barathi S, Pugazhendhi A, Ramkumar VS, Thi NBD, Arulselvi PI. Evaluation of $\mathrm{Cr}(\mathrm{VI})$ reduction mechanism and removal by Cellulosimicrobium funkei strain AR8, a novel haloalkaliphilic bacterium. J Hazard Mater. 2017;333:42-53. doi: 10.1016/j. jhazmat.2017.03.037

113. Nwodo UU, Green E, Okoh Al. Bacterial exopolysaccharides:functionality and prospects. Int J Mol Sci. 2012;13(11):14002-14015. doi: 10.3390/ ijms131114002

114. Moscovici M. Present and future medical applications of microbial exopolysaccharides. Front Microbiol. 2015;6:1012. doi: 10.3389/fmicb.2015.01012

115. McHugh DJ. Production, properties and uses of alginates. Production and Utilization of Products from Commercial Seaweeds. FAO Fish Tech Pap. 1987;88:58115.

116. Necas J, Bartosikova L, Brauner P, Kolar J. Hyaluronic acid (hyaluronan):a review. Vet Med (Praha). 2008;53:397-411. doi: 10.17221/1930-VETMED

117. Morris G, Harding S. Polysaccharides microbial. In Encyclopedia of Microbiology. Elsevier Inc. 2009:482494. doi: 10.1016/B978-012373944-5.00135-8

118. Sarilmiser HK, Oner ET. Investigation of anti-cancer activity of linear and aldehyde-activated levan from Halomonas smyrnensis AAD6 ${ }^{\top}$. Biochem Eng J. 2014;92:28-34. doi: 10.1016/j.bej.2014.06.020

119. Guimaraes JT, Silva EK, de Freitas MQ, de Almeida Meireles MA, da Cruz AG. Nonthermal emerging technologies and their effects on the functional properties of dairy products. Curr Opin Food Sci. 2018;22:62-66. doi: 10.1016/j.cofs.2018.01.015

120. Guimaraes JT, Balthazar CF, Silva R, et al. Impact of probiotics and prebiotics on food texture. Curr Opin Food Sci. 2020;33:38-44. doi: 10.1016/j. cofs.2019.12.002

121. Nehal F, Sahnoun M, Smaoui S, Jaouadi B, Bejar S, Mohammed S. Characterization, high production and antimicrobial activity of exopolysaccharides from Lactococcus lactis Fmou. Microb Pathog. 2019;132:1019. doi: 10.1016/j.micpath.2019.04.018

122. Yildiz H, Karatas N. Microbial exopolysaccharides: Resources and bioactive properties. Process Biochem. 2018;72:41-46. doi: 10.1016/j.procbio.2018.06.009 